\title{
SUBCLAVIAN VEIN CATHETERIZATION
}

\author{
William K. Nowill, M.D. and Francis B. Haber, M.D.*
}

Subclavian venepuncture was first described by Aubaniac in 1952. ${ }^{1}$ There have been a number of reports since then by DeBoscoli, ${ }^{2}$ Regnault, ${ }^{3}$ Keeri-Szanto, ${ }^{4}$ Lemoine and Tastet, ${ }^{5}$ Michaux, ${ }^{6}$ and Piscitelli. ${ }^{7}$ Keeri-Szanto reported a series of subclavian vein punctures performed at autopsy, with success of 94 per cent of 139 attempts. Ashbaugh in 1963 described 19 patients in whom subclavian catheters were used, and included among the advantages of this technique the ability to infuse blood and fluids rapidly, to monitor central venous pressure and to adminster hypertonic solutions without producing phlebitis or venous thrombosis. He reported four patients who had catheters in place for fourteen days or more. However, the catheters were changed every three days from one side to the other. He reported only one complication, that of pneumothorax in one patient. He listed other potential complications including division of the catheter, failure to insert the catheter into the vein, haemothorax, hydrothorax, septicaemia, and vein thrombosis.

In 1963, Davidson ${ }^{10}$ reported the use of this technique in 100 patients, the youngest of whom was three and one-half years! He reported six failures. $\mathrm{He}$ also reported the use of the supraclavicular route in 130 patients with no failures. In 1965, Matz ${ }^{11}$ reported six patients who developed complications with this technique, five being pneumothorax and one a hydrothorax. Also in 1965, Smith, Modell, Gaub and Moya ${ }^{12}$ reported that eight of 200 patients developed complications with this technique. They observed three haemothoraces, two pneumothoraces with subcutaneous emphysema requiring tracheostomy, one brachial plexus palsy, one septicaemia from local cellulitis, and one subcutaneous haematoma.

This report reviews experience with subclavian vein catheterization in a series of 765 patients over a period of seven years. The youngest patient was three days and the oldest 81 years. The catheters were kept in place on the average for one to six days although occasionally they were left in longer primarily for fluid and feeding therapy.

\section{TeChNique}

The subclavian vein is a continuation of the axillary vein. It arches over the first rib and cervical pleura beneath the clavicle. It is often two centimeters or more in diameter. At the point where it joins the internal jugular vein, the innominate vein is formed. It lies in front of and below the subclavian artery and is separated from the artery by the anterior scalenus muscle and phrenic nerve. The inferior trunk of the brachial plexus lies behind the vein.

To insert the catheter, the patient is placed supine with the head lowered and

'The Department of Anesthesiology, Arnot-Ogden Memorial Hospital, Elmira, New York, U.S.A. 
the feet and legs elevated. A small pillow is placed under the upper thoracic spine. The head is turned to the opposite side, which brings the subclavian vessels closer to the surface of the skin. Lowering the head and raising the legs is important in order to increase the pressure in the vein prior to puncture. At a point one centimeter to one inch below the clavicle, at the junction of its middle and medial third, $2 \mathrm{ml}$ of procaine 1 per cent or lidocaine 1 per cent is injected. A

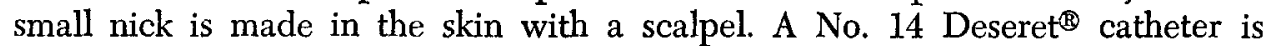
used for adults and a No. 17 catheter for children. The catheter and plastic guard are removed from the needle. A 2-cc or 5-cc slip-tip syringe is connected to the needle. The syringe must fit snugly so that no air leak can occur. The noedle is inserted through the skin at an angle heading toward the junction of the clavicle with the sternocleidomastoid muscle, at a depth such that the needle point impinges lightly against the clavicle. The needle point is then withdrawn and gently walked down the inferior aspect of the clavicle. This maneuver brings the point of the needle anterior to the first rib. With traction on the plunger of the syringe, the needle is then inserted until free flow of blood is obtained. The stylet is withdrawn approximately one inch from the catheter, which makes the leading inch of the catheter more pliable than the remainder. The hub of the needle is held at this position with a haemostat and the syringe is removed. Because of the position of the patient, blood flows from the needle. This is important, as it prevents air from entering the needle. The catheter is then inserted through the needle and should enter into the vein with little or no difficulty. If any resistance is met, the needle and catheter are withdrawn. No attempt is made to pull the catheter back through the needle, to avoid cutting off part of the catheter on the needle point. After the catheter enters through the needle into the vein, it is inserted nearly its full length and the needle withdrawn. The stylet is removed from the catheter and the intravenous tubing connected directly to the catheter. The catheter is then withdrawn so that its end is either in the subclavian vein or superior vena cava in the area of the right auricle. The catheter and needle are sewn to the skin in three places so that it is difficult to pull out the catheter inadvertently. A piece of adhesive tape is placed over the tip of the needle so that the point will not perforate the catheter. A dressing of either Bacitracin ${ }^{\circledR}$ or Neosporin ${ }^{\circledR}$ ointment is placed at the skin site. All connections are taped solidly together and the catheter needle and approximately 10 inches of intravenous tubing are taped in a loop to the chest. As soon as the infusion tubing has been connected to the catheter, the patient's position is changed from Trendelenburg to Fowler's to decrease the pressure in the subclavian vein and to prevent bleeding from the vein around the catheter.

The infusion is set up with two bottles - a primary bottle which remains connected directly to the infusion tubing and a secondary bottle through which the required fluids run. The primary bottle is never allowed to empty, to prevent an air embolism which might occur with the patient in a sitting position. The bottles are kept three to five feet above the patient so that changes in position of the patient (particularly lying on the side in which the subclavian catheter is placed) will prevent blood running back into the catheter and plugging it. A chest $\mathrm{x}$-ray is taken to ascertain the exact location of the catheter tip in relation to the right auricle. 
Nursing care is extremely important. Most of our success and lack of complications here have been due to diligent nursing care. The primary bottles are changed every 48 hours to prevent contamination from becoming a factor.

\section{Discussion}

In this series, the catheters were successfully placed in all but four patients. In a child, age three, who had a ruptured appendix with peritonitis, attempts were made to begin infusions, first with needles and then by cut-down into a vein. We were requested to place a subclavian catheter in this child. A simple error was made. The child should have been sedated. One attempt was made and the needle went directly into the subclavian artery. The needle was withdrawn and no complications ensued. The child was then sedated and a vein on the foot was used for a small catheter. We were unsuccessful in three other patients, one of whom was an obese woman in whom we attempted to place a subclavian catheter on the right and could not reach the vein. The attempt on the left was successful and the catheter remained in place for 19 days.

Early in the series, most of our use of this technique was in patients who had intravenous infusions through peripheral veins, but developed phlebitis. In these patients, subclavian catheterization was valuable. In one or two of these patients who expired, the subclavian vein at autopsy was free of any clot. In situations requiring massive blood replacement, subclavian vein catheterization has been most useful. To illustrate this point two case histories are presented.

A 50-year-old woman was admitted to undergo an oesophagectomy with interposition and anastomosis of the colon. Immediately prior to surgery, a catheter was placed in the right subclavian vein. During the postoperative period, the anastomosis broke down and she developed an empyema with a fistula from the oesophagus and colon through the chest to the skin. Septicaemia ensued, which was treated and apparently cured by intravenous administration of Keflin ${ }^{\circledR}$ and Chloromycetin ${ }^{\circledR}$. However, the patient finally developed massive gastrointestinal haemorrhage and expired. The subclavian catheter was in place for 66 days and through it she received 23 pints of blood, serum albumin, amino acids, a variety of antibiotics, and other parenteral fluids. No complication was noted from the prolonged use of the subclavian catheter.

A 42-year-old obese man was admitted with a bleeding duodenal ulcer. After infusion of nine pints of blood over a period of 24 hours, he had a subtotal gastrectomy. Postoperatively the duodenal stump blew out and surgical drainage was necessary. He developed septicaemia with daily temperatures of $106^{\circ} \mathrm{F}$. After a third operation, he had a complete wound dehisence. A left subclavian catheter was placed because every other available vein had been used and all had become thrombosed. Through this catheter Chloromycetin ${ }^{\circledR}, K f_{l i n}{ }^{\circledR}, K^{2}$ antrex ${ }^{\circledR}$, vitamins, serum albumin, whole blood, and intravenous fluids with glucose and potassium were administered. In addition, blood for electrolyte values, other chemical studies and blood cultures were taken from this catheter. It remained in place for 37 days with no complications, and the patient recovered and left the hospital.

The technique is useful in infants and children. We had five patients three years of age or younger, in whom there were problems of administrating paren- 
teral fluids or blood through peripheral veins. The youngest infant was three days of age and had multiple atretic areas of the intestinal tract corrected by surgery. This child died eight days postoperatively but fluids, serum albumin, and electrolytes were administered through a subclavian vein after failure of peripheral venous cut-down, scalp vein needles, and umbilical vein catheters.

One child, aged eleven months, had extensive burns of face, arms, legs, and chest. There were no peripheral veins which could be used. The left subclavian vein catheter was inserted and remained in place for five days, at which time it became plugged. Then a right subclavian catheter was placed and remained for five days.

In placing the subclavian catheter in children, it is important that they be anaesthetized or well sedated so that they do not move during placement of the needle.

We have had no complications from the use of this technique. However, possible complications should be listed as follows:

(1) Pneumothorax

(2) Hydrothorax or haemothorax

(3) Tearing of the vessel with massive haemorrhage

(4) Insertion of catheter into artery with arterial spasm, especially if irritating drugs are injected through the catheter

(5) Trauma or irritation of the brachial plexus

(6) Air embolism

(7) Bleeding from the catheter if the connection becomes dismantled

(8) Haematoma around the insertion site, caused by perforating the posterior wall of the subclavian vein

(9) Cutting off the end of the catheter by attempting to withdraw the catheter through the needle

(10) Over-enthusiastic administration of blood or fluid, with production of pulmonary edema

(11) Myocardial depression due to rapid administration of depressant drugs through the subclavian catheter. Injection of anaesthetic, narcotic, and sedative drugs must be made with care

(12) The use of subclavian catheters to obtain blood for haematocrit, blood volume or blood chemistry work should be done under medical supervision for two reasons:

(a) an undiluted sample of blood must be obtained and

(b) care must be used so that the patient does not develop an air embolism during manipulations of the catheter

(13) One should not use central venous pressure readings without integrating this information with information otherwise gained from examining the patient, such as blood pressure, blood volume, urine output, EkG, etc. A high venous pressure does not in itself mean either congestive heart failure or excess blood volume, and similarly a low venous pressure does not mean a low blood volume or low cardiac output. In taking central venous pressure readings one must be sure that the landmarks used are steady and that there is a free flow of fluid in and out of the catheter.

Subclavian catheters have been placed by the infraclavicular route in 765 
patients over a period of seven years with four failures of insertion. The technique of insertion of the catheter and maintenance of the intravenous fluid system must be meticulous. To be consistently successful this technique requires experience. In our hospital the technique by common consent of the Attending Medical Staff is performed essentially by four members of the Anaesthesia Staff. Because of frequency of use, all of these physicians have had a large experience in the insertion of these catheters and are quite adept at their use. Since the technique is used frequently, the Nursing Staff are well oriented in the care of the patients with subclavian catheters. To date, we have had no apparent complications and this procedure appears to be useful.

\section{RÉSUMÉ}

Au cours des sept dernières années, nous avons placé des cathéters dans la veine sous-clavière par la voie sousclaviculaire chez 765 malades; nous avons eu quatre insuccès d'insertion. La technique d'insertion du cathéter et le maintien de l'administration des liquides intraveineux doivent être suivis de façon méticuleuse. Pour conserver un haut pourcentage de succès, la technique exige une certaine expérience. Dans notre hôpital, avec l'assentiment du personnel médical, seulement quatre membres du département d'anesthésie pratiquent cette technique. A cause de l'usage fréquent de cette technique, ces médecins ont acquis une grande expérience dans l'insertion de ces cathéters et ils sont devenus très habiles. Pour la même raison : l'usage fréquent de cette technique, les infirmières sont bien familières avec les soins à donner aux malades porteurs de ces cathéters. Jusqu'à maintenant, nous n'avons pas eu de complications apparentes et cette technique semble être utile.

\section{REFERENCES}

1. Aubantac, R. L'injection intraveineuse sousclaviculaire. Avantages et technique. Presse med. 60: 1456 ( 1952 ).

2. DeBoscolr, G. G. Veias Sub-Clavias E Troncos Venosos Braquio-Cefalicos, Novas Vias De Acesso Para As Transfusoes Endovenosas. J. Pediat. Rio deJ. 21: 112-123 (1956).

3. Regnault, P. La voie intraveineuse sous-clavière. Un. med. Cad. 85: 827-29 (1956).

4. Keeri-Szanto, M.; Fortin, G.; \& Rious, A. La voie veineuse sous-clavière en anesthesie. Canad. Anesth. Soc. J. 4: 55-59 (1957).

5. Lemoine, J. \& TASTET, J. L'intraveinotherapie par voie sous-claviculaire. Anaesth. Analg. (Paris). 15: 16-25 (1958).

6. Michaux, H. Technique of subclavian venous puncture. Vie Med. 41: 83-86 (1960).

7. Pistelli, M.; Darin, G.; \& Dilazzaro, B. A valuable venous perfusion route: Aubaniac's subclavian route. Ann. Med. Nav. trop (Roma). 65: 31-8 (1960).

8. Keeri-Szanto, M. The Subclavian Vein a Constant and Convenient Intravenous Injection Site. Arch. Surg. 72: 179-181 (1956).

9. Ashbaugh, David \& Thomson, I. W. W. Subclavian Vein Infusion. Lancet. Ir. 1138-39 (1963).

10. Davidson, J. T.; Ben-Hur, N.; \& Nathan, H. Subclavian Venepuncture. Lancet. II. $1139-40$ (1963).

11. Matz, Robert. Complications of Determining the Central Venous Pressure. New Eng. J. Med. 273: 703 (1965).

12. Smith, B. E.; Modelt, J. H.; Gaub, M. L.; \& MoYa, F. Complications of Subclavian Vein Catheterization. Arch. Surg. 90: 228-29 (1965). 